never have been able to perceive the slightest real difference between Asiatic cholera and bad English choleraic diarrhoea, and $I$ have seen several cases of cholera in the last epidemic when a student at University College Hospital in London. Intense "præcordial anguish" was present in all my cases, and is a constant symptom in bad choleraic diarrhoea. I shall never forget the overpowering intensity of this symptom in a severe attack of choleraic diarrhoea I went through myself a few weelss after writing my paper.

Mr. MacDowall takes exception to my statement that "it is the purging that kills," inasmuch as many cholera patients die during reaction of a typhoid condition. This, of course, I, am well aware of, and when first I commenced using the treatment, when it was a last resort, I nearly lost patients from this febrile condition; but as I consider that the danger and severity of this reaction are directly proportional to the amount of the purging, and caused by the purging, and not a subtle manifestation of the unexhausted action of the cholera poison, I must still ad here to my original statement that "it is the purging that kills." I would even go a step farther, and assert the seeming paradox that I believe in cholera it is the purging that kills and not the cholera poison.

I am obliged to Mr. MacDowall for his fair and friendly criticism of my views and cases, but he would place me under a still greater obligation if he would again try the treatment as a first resort, and publish the result.

London, Oct. 21st, 1880.

$$
\text { I am, Sir, yours, \&c., }
$$

WM. HARDMAN.

\section{FARR TESTIMONIAL FUND.}

\section{To the Editor of THE LANCET.}

SIn,-I am desired by the Committee charged with the promotion of the Farr Testimonial Fund to request that you will add to their obligations by publishing in your next issue the following further list of subscriptions.

$$
\text { Faithfully yours, }
$$

$$
\text { Oct. 28th, } 1880 . \quad \text { NoEl A. Humphreys, Hon. Sec. }
$$

\begin{tabular}{|c|}
\hline \\
\hline Lewis, Waller A., M.B. \\
\hline Farre, Arthur, M.D, F.R.S. \\
\hline Sibley, Eeptimus W., MID. \\
\hline llif, W. I., M.D. $\ddot{\circ} \circ$ \\
\hline $\begin{array}{l}\text { Rogers, Henry, M.R.C.S.. } \\
\text { Hill Berkeley, F.R C.S. }\end{array}$ \\
\hline Hallett, T. G. P., F.S S. .. \\
\hline Hastings, G. W, M.P. .. \\
\hline Russell, Gon. F. A. R. \\
\hline Stepheneon, E.J. \\
\hline Wilkinson, R. . . .. \\
\hline Begley, iv. C., M.D... \\
\hline Baylis, Mrs. C. O. \\
\hline $\begin{array}{l}\text { Morris, Thomas, M.D. } \\
\text { Thomas, G. D. P., M.D. }\end{array}$ \\
\hline $\begin{array}{l}\text { Thomas, G, D. P., M.D. . } \\
\text { Priestles, W. O., M.D. .. }\end{array}$ \\
\hline Ace, Rev. D., D.D. . \\
\hline Wells, T. Spencer, F.R.CS. \\
\hline Tidy, C. M, M.B. \\
\hline Quain, R, G.R.C.S.,F.R.S. \\
\hline Gleaton, J. D., M.R C.S... \\
\hline Radford, Thomas, M D. \\
\hline Brown,J.B.,F.S.S., F.R.G.S. \\
\hline Roth, AI., II D. . \\
\hline Balfour, I. G., F.R.S. \\
\hline Mann, Horace .. .. \\
\hline Wood, Mrs. S. E. \\
\hline Westgartli, W. (znd don.) \\
\hline $\begin{array}{l}\text { Sutherland, Joh } \\
\text { Hawkesles, Tho }\end{array}$ \\
\hline Porter, H. iw., B.A. \\
\hline Winstone, Benj, M.D. \\
\hline Lee, John, I, $5, \mathrm{~A}$ \\
\hline Ballare, Edwa d, if D. .. \\
\hline
\end{tabular}

\section{Amount of Subscriptions already published, f9:5 Qs.}

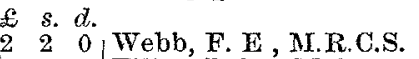

$$
\begin{aligned}
& 0 \text { Elliot, Robt. M.D. } \\
& 0 \text { Dickson, } \mathrm{K} \text {. } \mathrm{C} \text {. } \\
& 0 \text { Wrilliame, J. F., } \\
& 0 \text { Tytherıdge, } \dot{H} \text {. B. H. } \\
& 0 \text { Sayer, G. I. H. } \\
& \begin{array}{ll|l}
5 & 0 & \text { Waters, A. C. } \\
0 & 0 & \text { Wilkes, Jas., } \\
\hline & \text { R.C } & \text { S. }
\end{array} \\
& 0 \text { Davis, Theodore, M.R.C. } \\
& 0 \text { Foster, M., M.D. F R.S. }
\end{aligned}
$$

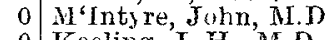

$$
\begin{aligned}
& 3 \text { K Keeling, J. H., M.D. } \\
& 10 \text { Langshaw, J. P.. F.R.C.S } \\
& 0 \text { Dunbar, Eliza W. M D. } \\
& 5 \text { Hollis, W. M., M.R.C.S. } \\
& 0 \text { Hughes, H. S., M.R } \\
& \text { 0 W'Tellar, E., M.D. } \\
& \text { 0 Filliam, Wm., M. B. } \\
& 0 \text { Tripe, J. W., M.D. } \\
& 0 \text { Sykes John } \\
& 0 \text { Eildowes, Alfred, M D. } \\
& \text { Eddowes, Wm., M R C.s. } \\
& 0 \text { Page, Herbert ir R CS. } \\
& 0 \text { Tuner, Geo., M } \\
& \text { 0 Rix, w. } \mathrm{H} \text {., M R.G. } \\
& \text { 0 Rix, W. H., M.R C.S. } \\
& \begin{array}{l}
0 \\
0 \\
\text { Wilson, J. H., M.K.Q.C.P. }
\end{array}
\end{aligned}
$$

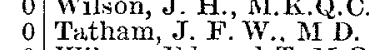

$$
\begin{aligned}
& 0 \text { Wilson, Wd ward T. M. B } \\
& 0 \text { Tillev, Samuel, F.R.C.S. } \\
& 0 \text { Thiey, Samuel, } \mathrm{F} \text {. }
\end{aligned}
$$

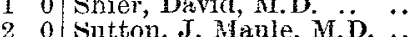

As the Committee proposes shortly to close the subscription list, intending subscribers, who have not yet intimated their intentim, are requested to communicate with the Hon. Sec. Ir. Toel 1. Hunubreys, General Register Office, Somerset House, London. W.C. All cheques or post-office orders should be crossed "Mlartin and Co."

A sur amounting to $\& 43810_{s}$. $3 d$. has been handed over to the govenors of the Lincoln Conuty Hosuital as the result of the Hospital Saturday movemeut.

\section{(Bbituaty.}

\section{DR. EDWARD ISAAC SPARKS.}

Tre death of this young physician, which took place on the 1lth inst. at Crewkerue, in Dorsetshire, has robbed the profession of a man who, had he been endowed with physical qualities in any way commensurate with those of his mind, must have risen to the very foremost rank. He was the younger son of Mr. William Sparks, J.P., and was born at Crewkerne on September 25th, 1843. He received the rudiments of his education at the grammar-school of his native town, whence he was subsequently removed to Harrow, and ultimately entered Corpus Christi College, Oxford. At college his career was one of very great distinction. He graduated in 1866 with a first class in Natural Science, and second class honours in Classics. In 1868 he was appointed Radcliffe Travelling Fellow, and between this and 1871, in fulfilment of the conditions of the Fellowship, he travelled throughout Europe, visiting the chief medical schools in France, Germany, and Italy, and acquiring a sound knowledge of the three chief Continental languages. After graduating in Arts at Oxford he entered at University College, London, where ha finished his medical education, graduating as M.B. in 1870, and taking the diploma of M.R.C.P. in $18 \% 2$

When Inr. Sparks settled in London in 1872 he had a right to be considered as one of the most highly educated members of the profession. Ancient and modern languiges, the natural seiences, and the most advanced views on medicine, both of England and the Continent, he had made his own. But he was not a man to be led exclusively by the views and dogmas of others, and we accordingly find hin eagerly seeking for opportunities of clinical study in the rich field afforded hy our great metropolis. He became physician to the Mount-street Dispensary, the Children's Dispensary in Bell-street, and also to the Royal Hospital for Children and Women in the Waterloo-road. In 1874 he was made physician to the skin department at Charingcoss Hospital, and also subsequently had charge of a clinic for diseases of the throat.

This excessive devotion to the most unwholesome department of medical practice-viz., the out-patient practice of hospitals and dispensaries, soon told upon a constitution which was always feeble. In 1875 ministakable sions of phthisis became manifest, and Dr. Sparks, who had ouly shortly before been married, found himself compelled to leave London for the south of France. His intention was to practise at Mentone, but at the ontset his riews were frustrated by the French regulation with resard to foreign practitioners. He was not a man to yield easily to ohstacles, and accordingly in May, 1877, he qualified as an officier de santé at Marseilles, and began to practise systenatically at Mentone. In the same year he published an English translation of Binz's Elements of Therapeutics, a work which was well received. From time to time Dr. Sparks published various papers on skin diseases, and notably a paper on "A Disease produced by the Acarus folliculorum," which appeared in the Medico-Chirurgicel Transactions for 1874. After settling in Mentone, Dr. Sparks continued to suffer at intervals from lung truble aud also from profuse hæmaturia and albuminuria, but his bodily condition in no way dismayed him. He foresaw the result cleally enough, and contemplated his approaching end with a calmness which was little short of sub ime. In the sixty-second volume of the Medico-Chicurgisal Transictions he published, in connexion with his friend, Dr. Mitchell Bruce, a paper on the effect of diet, lest, and exerei=e in chronic nephiris, and the value of the paper and the respect for the author will alike be increased when it is known that he found the materials for the work in lis own condition, and that, in fact, all the observations recorded in the paper in question were made upon himself.

Last year Dr. Sparks published a book upon the Riviera, which we reviewed most favomrably in Augnst last, and we have no doubt that it will rove a valuable work of reference.

It is needless to add that Dr. Sparks possessed a most unusual amount of energy combined with great scientific acumen. The cutalugrue of his writings and a record of their reception by the profession are a sufficitnt evidence of that. 